\section{Determination of Silicon Concentration in Some Horticultural Plants}

\author{
Brian K. Hogendorp \\ Department of Natural Resources and Environmental Sciences, University of \\ Illinois, Urbana, IL 61801
}

Raymond A. Cloyd ${ }^{1}$

Kansas State University, Department of Entomology, 123 Waters Hall, Manhattan, KS 66506-4004

\section{John M. Swiader \\ Department of Natural Resources and Environmental Sciences, University of Illinois, Urbana, IL 61801}

\begin{abstract}
Additional index words. silicon-fertilizer, potassium-silicate fertilizer, quantification technique, greenhouse, horticulture
\end{abstract}

\begin{abstract}
Although silicon is not an essential element, it is taken up by plants but is rarely quantified. Therefore, this study quantified the silicon concentration in $\mathbf{1 0}$ commonly grown horticultural plants including meadow sage (Salvia $\times$ sylvestris), tickseed (Coreopsis verticillata), garden phlox (Phlox paniculata), New England aster (Symphyotrichum novae-angliae), Chinese astilbe (Astilbe chinensis), coral flower (Heuchera hybrid), garden zinnia (Zinnia elegans), French marigold (Tagetes patula), sweet basil (Basil spp.), and rosemary (Rosmarinus officinalis) using a plant alkaline fusion technique, which involved dry-ashing plant tissue samples and measuring color development with a spectrophotometer. Both zinnia and aster accumulated substantially more silicon from the municipal water source and growing medium (5365 and $4797 \mathrm{mg} \cdot \mathrm{kg}^{-1}$ silicon, respectively) than the other plants evaluated, which had concentrations less than $2500 \mathrm{mg} \cdot \mathrm{kg}^{-1}$ silicon. This study is just one of a few in which the silicon concentration in various horticultural plants has been quantified. Consequently, this may lead to better understanding those plants that will or will not benefit from applications of silicon-based fertilizers to promote coldhardiness and/or plant resistance to fungal pathogens and insect pests.
\end{abstract}

The function of silicon in horticultural crops is not well understood, primarily because silicon is not considered an element essential for plant growth as indicated by the "criteria of essentiality" defined by Arnon and Stout (1939) (Epstein, 1994). Silicon is primarily available from water sources, growing media, and fertilizers. In addition, negligible amounts may be present in dust (Woolley, 1957). It has been determined that greenhouse crops grown in rockwool have lower concentrations of silicon as a result of a soluble silicon deficiency in the growing medium and the hydroponic fertilizer solution (Voogt and are typically avoided through ambient water silicon contamination (Woolley, 1957). It has

\footnotetext{
Received for publication 14 May 2012. Accepted for publication 24 Sept. 2012.

We thank Emily Nixon, Kevin Starks, and Cary Mitchell for technical assistance; and Ruth Green, Debbie Black, Heather Lash, Kelly Alsip, and the University of Illinois Plant Health Care staff. We also thank Drs. Donald Briskin, Art Spomer, and James Stucki for technical advice and assistance. In addition, we express our gratitude to Mary Beth Kirkum (Department of Agronomy; Kansas State University, Manhattan, KS) for reviewing a previous draft the manuscript.

${ }^{1}$ To whom reprint requests should be addressed; e-mail rcloyd@ksu.edu.
} Sonneveld, 2001). However, silicon deficiencies been widely accepted that silicon is a "beneficial" element based on plant responses such as growth, development, and yield increases of select plant species (Bidwell, 1974; Hopkins and Hüner, 2004; Ma et al., 2001; Ma and Yamaji, 2006; Marschner, 1995). Furthermore, it has been suggested that the addition of silicon-based fertilizers may increase plant resistance to fungal pathogens and insect pests, although the mechanisms associated with silicon-mediated resistance are not well understood (Bélanger et al., 1995; Bowen et al., 1992; Keeping and Kvedaras, 2008; Ma and Takahashi, 2002; Sangster and Hodson, 1986; Sangster et al., 2001). In addition, soluble silicon may act as a modulator for induced resistance so that plants respond faster to abiotic and/or biotic stress (Fauteux et al.,
2006). However, to assess the benefits of applying silicon-based fertilizers, it is essential to determine quantitatively the silicon concentrations in plants. Nonetheless, there is minimal to no information associated with the concentration of silicon in plant tissues, particularly of horticultural crops. Therefore, the objective of this study was to establish baseline silicon concentrations of a variety of commonly grown horticultural plant species irrigated with municipal water sources in growing medium without supplemental silicon-based fertilizers using the plant alkaline fusion technique that was developed to quantify the concentration of silicon in plants (Hogendorp et al., 2011).

\section{Materials and Methods}

Horticultural plants used in this study were grown on raised wire-mesh benches in glassglazed greenhouses located in the Plant Health Care Greenhouse Facility at the University of Illinois (Urbana-Champaign, IL). The scientific name, common name, and cultivar of each of the plants evaluated are presented in Table 1. Fifteen to 20 plants of each species were obtained from the Ball Ornamental Company (West Chicago, IL). Plants were started from rooted plugs contained in 24 round-cell ProTrays (Hummert International ${ }^{\mathrm{TM}}$, Earth City, $\mathrm{MO})$. Cuttings were taken from stock plants or seedlings were grown from seed (Table 1). Plants were transplanted into Elite 600 pots (7.5 L) (ITML Ornamental Products Inc., Brantford, Canada) filled with either GP2 nursery growing medium (Midwest Groundcovers, St. Charles, IL) or with Sunshine ${ }^{\circledR}$ LC1 growing medium (Sun Gro Horticulture ${ }^{\odot}$ Canada Ltd., Bellevue, WA). The GP2 nursery growing medium was comprised of peatmoss, perlite, composted pine bark, and highly processed and composted cow manure. The Sunshine ${ }^{\circledR}$ LC1 growing medium consisted of $70 \%$ to $80 \%$ Canadian sphagnum peatmoss, perlite, dolomitic limestone, gypsum, and a wetting agent. All plants received Peter's ${ }^{\circledR} 20 \mathrm{~N}-4.4 \mathrm{P}-16.6 \mathrm{~K}$ fertilizer (ScottsSierra Ornamental Products, Marysville, $\mathrm{OH}$ ) applied in a constant liquid feed program at $200 \mathrm{ppm}$ nitrogen. The temperature inside the greenhouses was maintained at $24 \pm 2{ }^{\circ} \mathrm{C}$ (day) and $18 \pm 2{ }^{\circ} \mathrm{C}$ (night). All plants were grown under natural daylight conditions with no supplemental lighting. All plants were watered, when needed, using a municipal
Table 1. Descriptive list of horticultural plant species used, including scientific name, common name, cultivar, and propagation method (starting material).

\begin{tabular}{llll}
\hline Scientific name & Common name & Cultivar & Starting material \\
\hline Salvia $\times$ sylvestris L. & Meadow sage & May night & Plugs \\
Coreopsis verticillata L. & Tickseed & Moonbeam & Plugs \\
Phlox paniculata L. & Garden phlox & David's white & Plugs \\
Symphyotrichum novae-angliae L. & New England aster & Purple dome & Plugs \\
Astilbe chinensis (Maxim.) Franch & Chinese astilbe & Maggie Daley & Plugs \\
Heuchera hybrid L. & Coral flower & Licorice & Plugs \\
Zinnia elegans Jacq. & Garden zinnia & Short stuff & Seed \\
Tagetes patula L. & French marigold & Safari queen & Seed \\
Basil spp. L. & Sweet basil & Genovese & Seed \\
Rosmarinus officinalis L. & Rosemary & Unnamed & Cuttings \\
\hline
\end{tabular}


water source, which was tap water from Champaign-Urbana, IL.

Samples were harvested from each plant species by removing the aboveground portions (flowers, leaves, branches, and stems) and placing the plant material into a \#20 brown paper bag (Commercial Bag and Supply, Des Moines, IA). Five replicates (individual plants) of each plant species were harvested and used to establish baseline silicon concentrations. The garden zinnia, sweet basil, and French marigold plants were grown for $65 \mathrm{~d}$ and harvested on 9 Apr. 2008. The tickseed, garden phlox, and the aster plants were grown for $73 \mathrm{~d}$ and harvested on $1 \mathrm{Apr}$. 2008. The meadow sage, Chinese astilbe, and coral flower plants were grown for $59 \mathrm{~d}$ and harvested on 1 Apr. 2008. A plant alkaline fusion technique was used to quantify the silicon concentration in each of the 10 plant species. This procedure, which is described more thoroughly in Hogendorp et al. (2011), involved tissue samples from all plant species dried in a gravimetric convection oven (Precision Scientific Group, Chicago, IL) set at $64 \pm 2{ }^{\circ} \mathrm{C}$ until the plant tissue reached a constant weight. The dried plant tissue was then ground into a fine homogenous powder using a cyclone sample mill (Model 3010-030 UDY Corporation, Fort Collins, CO) fitted with a 1-mm screen (Gaines et al., 1987). The dried ground plant tissue was placed in a \#7 coin envelope $(8.9 \times 16.5 \mathrm{~cm})$ (Office Depot, Inc., Delray Beach, FL) and stored at $21 \pm 2{ }^{\circ} \mathrm{C}$. Before analysis, plant tissue samples were re-dried in the gravimetric oven set at $85{ }^{\circ} \mathrm{C}$ for $2 \mathrm{~h}$, mixed thoroughly, and then weighed for dry-ashing.

Fifty milligrams of dried, ground plant tissue was placed in 20-mL nickel crucibles fitted with corresponding nickel lids (Fisher Scientific International, Fairlawn, NJ) and ashed in a muffle furnace (Hytherm Co., Pennsauken, NJ) set at $550{ }^{\circ} \mathrm{C}$ for a minimum of $4 \mathrm{~h}$ and then digested. Two grams of anhydrous granular sodium hydroxide was added to each nickel crucible. The covered crucible was placed on an iron wire-gauze screen and then positioned on a ring stand. A standard grid-top adjustable natural gas Bunsen burner was ignited below the nickel crucible/ring stand apparatus contained within an operating fume hood. After $5 \mathrm{~min}$ had elapsed, the warm nickel crucible was gently swirled using a pair of tongs, which prevented the ash from adhering to the sides of the nickel crucible. The crucible was then returned to the ring stand for 10 min (Jones and Dreher, 1996; Volk and Weintraub, 1958). The alkaline fusion process resulted in a clear liquid-molten mixture. The crucible was then cooled, resulting in a white to purple sodium-silicate fusion cake located at the bottom of the nickel crucible. Approximately $20 \mathrm{~mL}$ of deionized/ distilled (d/d) water was added to the nickel crucible. The crucible remained idle for 6 to $8 \mathrm{~h}$ to dissolve the fusion cake. Finally, the silicon sample solution was transferred to a 250-mL volumetric flask and brought to volume with $\mathrm{d} / \mathrm{d}$ water.

A $25-\mathrm{mL}$ aliquot of the silicon sample solution was transferred to a $50-\mathrm{mL}$ polypropylene beaker using a volumetric pipette. The silicon sample aliquot was acidified with $10 \mathrm{~mL}$ of $1 \mathrm{~N} \mathrm{H}_{2} \mathrm{SO}_{4}$ followed by the addition of $10 \mathrm{~mL}$ of ammonium paramolybdate tetrahydrate solution. More detailed information associated with this portion of the procedure is provided in Hogendorp et al. (2011). The silicon sample was agitated for $15 \mathrm{~min}$ and then remained idle for another $15 \mathrm{~min}$ to allow for full color development. Measurements were taken using a spectrophotometer (Model ultraviolet-160; Shimadzu Corporation, Kyoto, Japan) at $820 \mathrm{~nm}$.

New colorimetric reagents were prepared every $\approx 7 \mathrm{~d}$ because the ANSA (1-amino-2napthol-4-sulfonic acid) solution would transition from a yellow to a dull yellow-brown color and lose sensitivity if maintained too long (longer than $7 \mathrm{~d}$ ) (Hogendorp et al., 2011). The ammonium paramolybdate tetrahydrate solution was discarded if a white precipitate formed, which commonly occurred after 10 to $12 \mathrm{~d}$; however, precipitates would form sooner if the solution was acidic. A new solution of $5 \mathrm{~N}$ sodium hydroxide was prepared with every new ammonium paramolybdate tetrahydrate solution; otherwise, this would be a source of silicon contamination.

Statistical analysis. Data associated with the silicon concentrations $\left(\mathrm{mg} \cdot \mathrm{kg}^{-1}\right)$ of the 10 horticultural plant species were analyzed using an analysis of variance with plant species as the main effect. Any significant differences were separated using a Tukey's Studentized test for least squares means separation adjusted for multiple comparisons (SAS Institute, 2002).

\section{Results and Discussion}

Zinnia and aster accumulated substantially more silicon from the municipal water source (5365 and $4796 \mathrm{mg} \cdot \mathrm{kg}^{-1}$ silicon, respectively) compared with the other plants evaluated, which accumulated less than $3000 \mathrm{mg} \cdot \mathrm{kg}^{-1}$ silicon (Table 2). These plants were grown under conditions similar to a greenhouse production system, not manipulated with purified laboratory grade water, and without a supplemental silicon-based fertilizer. As such, it is not possible to discern if the addition of supplemental silicon-based fertilizers will benefit these plant species other than increasing the overall silicon concentration. Therefore, we hypothesize that zinnia, which has an initial high silicon concentration, may benefit more from silicon-based fertilizer applications. Frantz et al. (2008) found that the silicon content of zinnia leaves was only $31 \mathrm{mg} \cdot \mathrm{kg}^{-1}$ when grown in purified laboratory water, but leaf tissue accumulated up to $11,750 \mathrm{mg} \cdot \mathrm{kg}^{-1}$ silicon (determined colorimetrically) when $2.0 \mathrm{~mm}$ potassium silicate fertilizer was added to the nutrient solution. This indicates that approximately half of the silicon accumulated $\left(5,365 \mathrm{mg} \cdot \mathrm{kg}^{-1}\right.$ silicon compared with $11,750 \mathrm{mg} \cdot \mathrm{kg}^{-1}$ silicon) in zinnia plants was fulfilled by our municipal water source and possibly the growing medium. Further studies are needed to determine if increased silicon concentrations in zinnia leaf tissue confers resistance to abiotic stresses, disease, and/or insect pests.

A plant species that may not benefit from supplemental silicon-based fertilizer applications is marigold. Frantz et al. (2008) reported that 'African Atlantis Primrose' marigold, Tagetes erecta L. plants, which received a nutrient solution containing $2.0 \mathrm{~mm}$ potassium silicate fertilizer, had $486 \mathrm{mg} \cdot \mathrm{kg}^{-1}$ silicon in the leaf tissues compared with $129 \mathrm{mg} \cdot \mathrm{kg}^{-1}$ silicon (determined colorimetrically) when plants were grown in a nutrient solution prepared with purified, laboratorygrade water without any silicon-based fertilizer, a difference of $357 \mathrm{mg} \cdot \mathrm{kg}^{-1}$ silicon. The French marigold plants in our study accumulated $625 \mathrm{mg} \cdot \mathrm{kg}^{-1}$ silicon, which was higher than the silicon-treated 'African Atlantis Primrose' marigold, T. erecta, plants used by Frantz et al. (2008) possibly because of the soluble monosilicic acid levels in municipal water supplies provided ample silicon for these plant species. In addition, the municipal water sources of Champaign-Urbana, IL, may have silicon levels higher than $2.0 \mathrm{~mm}$ silicon. Furthermore, French marigold may be more efficient in absorbing silicon from nutrient solutions than $T$. erecta.

The other horticultural plants evaluated in our study including coral flower $\left(555 \mathrm{mg} \cdot \mathrm{kg}^{-1}\right.$ silicon), rosemary (1053 $\mathrm{mg} \cdot \mathrm{kg}^{-1}$ silicon), and astilbe (1411 $\mathrm{mg} \cdot \mathrm{kg}^{-1}$ silicon) did not accumulate substantial concentrations of silicon and as such would be categorized as "silicon rejectors" according to Ma et al. (2001). We did not test whether applications of supplemental silicon-based fertilizers will increase silicon concentrations in plant tissues

Table 2. Silicon concentration $\left(\mathrm{mg} \cdot \mathrm{kg}^{-1}\right), \mathrm{SD}\left(\mathrm{mg} \cdot \mathrm{kg}^{-1}\right)$, and $\mathrm{CV}(\%)$ of 10 commonly grown horticultural plant species using the plant alkaline fusion technique silicon quantification procedure. ${ }^{\mathrm{z}}$

\begin{tabular}{|c|c|c|c|c|c|}
\hline Scientific name & Common name & Cultivar & $\begin{array}{l}\text { Silicon concn } \\
\left(\mathrm{mg} \cdot \mathrm{kg}^{-1}\right)\end{array}$ & $\begin{array}{c}\mathrm{SD} \\
\left(\mathrm{mg} \cdot \mathrm{kg}^{-1}\right)\end{array}$ & $\begin{array}{l}\mathrm{CV} \\
(\%)\end{array}$ \\
\hline Zinnia elegans Jacq. & Zinnia & Short stuff & $5365 \mathrm{a}^{\mathrm{y}}$ & 855 & 15. \\
\hline Symphyotrichum novae-angliae L. & Aster & Purple dome & 4796 a & 464 & 9 \\
\hline Phlox paniculata $\mathrm{L}$. & Phlox & David's white & $2427 \mathrm{~b}$ & 640 & 26. \\
\hline Coreopsis verticillata L. & Coreopsis & Moonbeam & $2219 \mathrm{bc}$ & 31 & \\
\hline Astilbe chinensis (Maxim.) Franch & Astilbe & Maggie Daley & $1411 \mathrm{~cd}$ & 345 & 24 \\
\hline Salvia $\times$ sylvestris $\mathrm{L}$ & Salvia & May night & $1070 \mathrm{~d}$ & 292 & 27. \\
\hline Rosmarinus officinalis L. & Rosemary & Unnamed & $1053 \mathrm{~d}$ & 283 & 26. \\
\hline Basil spp. L. & Sweet basil & Genovese & $1052 \mathrm{~d}$ & 182 & 17. \\
\hline Tagetes patula $\mathrm{L}$. & French marigold & Safari queen & $624 \mathrm{~d}$ & 43 & 7 \\
\hline Heuchera hybrid L. & Coral flower & Licorice & $555 \mathrm{~d}$ & 30 & \\
\hline
\end{tabular}

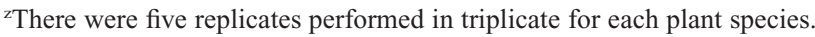

${ }^{\mathrm{y}}$ Means followed by a common letter within a column are not significantly different $(P>0.05)$ as determined by Tukey's Studentized range test. 
or if increased silicon content would benefit these plant species such as improving water relations, increasing cold-hardiness, and enhancing disease and/or insect resistance.

One study reported a number of horticultural plants including zinnia (Zinnia elegans Jacq), impatiens (Impatiens wallerana Hook. f), New Guinea impatiens (Impatiens hawkeri Bull.), verbena (Verbena $\times$ hybrida Voss), vinca, [Catharanthus spp. (L.) G. Don], and calibrachoa (Calibrachoa $\times$ hybrid Llave \& Lex.) actually respond to silicon fertilization with increased silicon contents in the leaves (Frantz et al., 2008). The plants used in that study were grown in 18 mega-ohm purified, "silicon-free" laboratory-grade water. However, it is not apparent if municipal or wellwater sources, commonly used in greenhouse production systems, would supply enough silicon to reach luxury status on their absorption curves (Marschner, 1995) or if additional supplemental silicon-based fertilizers are required.

It is important to determine if applications of silicon-based fertilizers to horticultural plants will provide benefits associated with increased heat tolerance, drought tolerance, cold-hardiness, and enhanced resistance to fungal infections and/or insect infestations. All these benefits have been affiliated with elevated silicon contents in specific agricultural crops such as rice, sugarcane, and certain cereals (Blackman, 1968; Jones and Handreck, 1967; Nayar et al., 1975). However, studies have shown that applications of silicon-based fertilizers to coleus [Solenstemon scutellarioides (L.)], fiddleleaf fig (Ficus lyrata Warb.), and poinsettia (Euphorbia pulcherrima Willd. ex Klotzsch) did not provide resistance against the citrus mealybug (Planococcus citri Risso) and greenhouse whitefly (Trialeurodes vaporariorum Westwood) (Hogendorp et al., 2009a, 2009b, 2010). In addition, Ranger et al. (2009) reported that nutrient solutions amended with potassium silicate did not affect the prereproductive period and survival of the green peach aphid (Myzus persicae Sulzer) reared on $Z$. elegans, whereas total cumulative fecundity and the intrinsic rate of increase were slightly reduced; however, this was only a modest increase in resistance levels.

Frantz et al. (2008) reported substantial differences in the silicon concentration of certain plant species when comparing the inductively coupled plasma optical emission spectrometry (ICP-OES) silicon determination procedure used by the U.S. Department of Agriculture-Agricultural Research Service laboratory that uses a separate colorimetric silicon determination procedure. However, there was no explanation to account for the differences in the silicon concentrations obtained between the silicon determination procedures. The plant species that differed substantially in silicon concentrations included snapdragon (Antirrinum majus L. 'Rocket White'), impatiens (Impatiens wallerana Hook. f. 'Super Elfin White'), New Guinea impatiens (Impatiens hawkeri Bull. 'Sonic Light Lavender'), and poinsettia (E. pulcherrima
'Freedom Red'). It was suggested that digestion of certain plant species may result in unknown compounds in the matrices, which could significantly affect the quantification procedure (Jonathan Frantz, personal communication). However, it is not known if these matrices interfere with the ICP-OES or the colorimetric procedure, and as such, further investigation is warranted. It is difficult to ascertain if the addition of supplemental silicon-based fertilizers will benefit these plant species, although it is possible that zinnia, which already has a high silicon concentration, may profit the most from silicon-based fertilizer applications.

In conclusion, the current study is just one of a few to quantify the silicon concentration in a variety of different horticultural crops. Silicon determinations are an initial step toward evaluating whether any of these plants benefit from applications of silicon-based fertilizers in regard to promoting cold-hardiness and/or plant resistance to fungal pathogens and/or insect pests. Therefore, further research needs to be conducted on the effect of silicon on the performance and resistance of horticultural crops.

\section{Literature Cited}

Arnon, D.I. and P.R. Stout. 1939. The essentiality of certain elements in minute quantity for plants with special reference to copper. Plant Physiol. 14:371-375.

Bélanger, R.R., P.A. Bowen, D.L. Ehret, and J.G. Menzies. 1995. Soluble silicon-Its role in crop and disease management of greenhouse crops. Plant Dis. 79:329-336.

Bidwell, R.S. 1974. Soil and mineral nutrition, p. 225-248. In: Plant physiology. Macmillan Publishing, New York, NY.

Blackman, E. 1968. The pattern and sequence of opaline silica deposition in rye (Secale cereale L.). Ann. Bot. (Lond.) 32:207-218.

Bowen, P., J. Menzies, D. Ehret, L. Samuels, and A.D.M. Glass. 1992. Soluble silicon sprays inhibit powdery mildew development on grape leaves. J. Amer. Soc. Hort. Sci. 117:906-912.

Epstein, E. 1994. The anomaly of silicon in plant biology. Proc. Natl. Acad. Sci. USA 91:1117

Fauteux, F., F. Chain, F. Belzile, J.G. Menzies, and R.R. Bélanger. 2006. The protective role of silicon in the Arabidopsis-powdery mildew pathosystem. Proc. Natl. Acad. Sci. USA 103: 17554-17559.

Frantz, J.M., J.C. Locke, L. Datnoff, M. Omer, A. Widrig, D. Sturtz, L. Horst, and C.R. Krause. 2008. Detection, distribution, and quantification of silicon in floricultural crops utilizing three distinct analytical methods. Commun. Soil Sci. Plant Anal. 39:2734-2751.

Gaines, C.S., R.E. Miller, J.R. Donelson, and M.M. Bean. 1987. Optimizing grinder type and methods of expressing wheat meal particle size for wheat texture (hardness or softness) measurement and near-infrared reflectance spectroscopy. Cereal Chem. 64:46-49.

Hogendorp, B.K., R.A. Cloyd, and J.M. Swiader. 2009a. Effect of silicon-based fertilizer applications on the reproduction and development of the citrus mealybug (Hemiptera: Pseudococcidae) feeding on green coleus. J. Econ. Entomol. 102: 2198-2208.
Hogendorp, B.K., R.A. Cloyd, and J.M. Swiader. 2009b. Silicon-based fertilizer applications have no effect on the reproduction and development of the citrus mealybug, Planococcus citri Risso (Hemiptera: Pseudococcidae), feeding on fiddleleaf fig, Ficus lyrata (Warb.). HortScience 44:1616-1621.

Hogendorp, B.K., R.A. Cloyd, C. Xu, and J.M. Swiader. 2010. Effect of silicon-based fertilizer applications on nymphal development and adult emergence of the greenhouse whitefly (Hemiptera: Aleyrodidae) feeding on poinsettia. J. Entomol. Sci. 45:150-169.

Hogendorp, B.K., J.M. Swiader, and R.A. Cloyd 2011. Plant alkaline fusion technique followed by colorimetric procedure for the detection and quantification of total silicon in ornamental plants. Commun. Soil Sci. Plant Anal. 42:7592.

Hopkins, W.G. and N.P. Hüner. 2004. Plants and inorganic nutrients, p. 247-258. In: Witman, K. (ed.). Introduction to plant physiology. $3^{\text {rd }} \mathrm{Ed}$. John Wiley and Sons, Hoboken, NJ.

Jones, L.H. and K.A. Handreck. 1967. Silica in soils, plants, and animals. Adv. Agron. 19:107149

Jones, R.L. and G.B. Dreher. 1996. Silicon, p. $627-$ 637. In: Methods of soil analysis. Part 3. Chemical methods-SSSA Book Series no. 5. Madison, WI.

Keeping, M.G. and O.L. Kvedaras. 2008. Silicon as a plant defense against insect herbivory: Response to Massay, Ennos, and Hartley. J. Anim. Ecol. 77:631-633.

Ma, J.F., Y. Miyake, and E. Takahashi. 2001 Silicon as a beneficial element for crop plants, p. 17-40. In: Datnoff, L.E., G.H. Snyder, and G.H. Korndörfer (eds.). Silicon in agriculture. Elsevier, Amsterdam, The Netherlands.

Ma, J.F. and E. Takahashi. 2002. Soil, fertilizer, and plant silicon research in Japan. Elsevier, Amsterdam, The Netherlands.

Ma, J.F. and N. Yamaji. 2006. Silicon uptake and accumulation in higher plants. Trends Plant Sci. 11:392-397.

Marschner, H. 1995. Mineral nutrition of higher plants. Academic Press, London, UK.

Nayar, P.K., A.K. Misra, and S. Patnaik. 1975. Rapid microdetermination of silicon in rice plant. Plant Soil 42:491-494.

Ranger, C.M., A.P. Singh, J.M. Frantz, L. Canas, J.C. Locke, M.E. Reding, and N. Vorsa. 2009. Influence of silicon on resistance of Zinnia elegans to Myzue persicae (Hemiptera: Aphididae). Environ. Entomol. 38:129-136.

Sangster, A.G. and M.J. Hodson. 1986. Silica in higher plants, p. 90-111. In: Evered, D. and M. O'Connor (eds.). Silicon biochemistry. John Wiley \& Sons, Chichester, Sussex, UK.

Sangster, A.G., M.J. Hodson, and H.J. Tubb. 2001. Silicon deposition in higher plants, p. 85-113. In: Datnoff, L.E., G.H. Snyder, and G.H. Korndörfer (eds.). Silicon in agriculture. Elsevier, Amsterdam, The Netherlands.

SAS. Institute. 2002. SAS/Stat user's guide, version 9.1. SAS Institute, Inc., Cary, NC.

Volk, R.J. and R.L. Weintraub. 1958. Microdetermination of silicon in plants. Anal. Chem. 30:1011-1014.

Voogt, W. and C. Sonneveld. 2001. Silicon in horticultural crops grown in soilless culture, p. 115-132. In: Datnoff, L.E., G.H. Snyder, and G.H. Korndörfer (eds.). Silicon in agriculture. Elsevier, Amsterdam, The Netherlands.

Woolley, J.T. 1957. Sodium and silicon as nutrients for the tomato plant. Plant Physiol. 32:317-321. 